\title{
Currículo de Autores
}

\section{César Gil}

Lcdo. en Contaduría Pública, egresado de la Universidad de Carabobo, Venezuela. Actualmente trabaja en Infosys Naguanagua, Edo. Carabobo 2 años de experiencia como asistente administrativo.

\section{Conalis CNartinez}

Lcda. en Contaduría Pública, egresada de la Universidad de Carabobo, Venezuela,

Valencia - Estado Carabobo. Contador Público de libre ejercicio profesional.

\section{Dennys Rodriqueg}

Lcda. en Contaduría Pública, egresada de la Universidad de Carabobo, Venezuela, Valencia - Estado Carabobo. Contador Público de libre ejercicio profesional.

\section{Fstefany Vasques}

Lcda. en Contaduría Pública, egresada de la Universidad de Carabobo, Venezuela,

Valencia - Estado Carabobo. Contador de libre ejercicio.

\section{Francisca Gómes}

Lcda. en Contaduría Pública, egresada de la Universidad de Carabobo, Venezuela Actualmente trabaja en Chimo San Carleño. Valencia, Edo Carabobo. 5 años de experiencia como asistente administrativo.

\section{Gabriela Mega}

Lcda. en Contaduría Pública, egresada de la Universidad de Carabobo, Venezuela, Valencia Estado Carabobo. Especialista en auditoría financiera. Contador en la firma ABREU \& ASOC. 


\section{Currículo de Autores}

\section{Tuette CMontenegro}

Lcda. en Contaduría Pública, egresada de la Universidad de Carabobo, Venezuela, Valencia Estado Carabobo. Especialista en el área de Auditoria. De libre ejercicio.

\section{Ygcibel Gavrido}

Ingeniero en Petróleo, egresada de la Universidad del Zulia, Núcleo Costa Oriental del lago. Venezuela. Magíster Scientiarum en Gerencia de Empresas. Mención: Gerencia de Operaciones. Universidad del Zulia, Núcleo Costa Oriental del lago. Venezuela. 


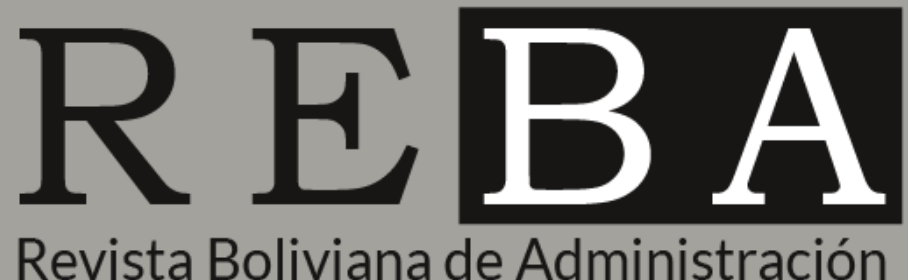

VOLUMEN 2 NÚMERO 4 JULIO - DICIEMBRE 2020

ISSN: 2710-0863

ISSN-L: 2710-0863

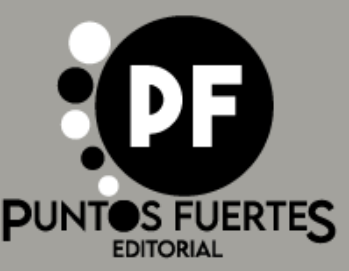

